\title{
Micrococcus violagabriellae Castellani
}

\author{
BY K. J. STEEL \\ National Collection of Type Cultures, Colindale Avenue, London, N.W.9
}

(Received 5 February 1964)

SUMMARY

The biochemical and cultural characters of Micrococcus violagabriellae Castellani were examined, and the cultural conditions necessary for pigment production investigated; iron and manganese were essential for pigmentation. Some pigment-containing material was isolated and its simple properties were examined. Taxonomically, the organism might warrant sub-specific rank as Staphylococcus epidermidis (or S. saprophyticus) var. violagabriellae.

\section{INTRODUCTION}

A staphylococcus which under certain circumstances produced purple colonies was described by Castellani (1955), who named it Micrococcus violagabriellae. The organism was first isolated from an erythematous disease of the axilla in American sailors who had apparently contracted the infection in the West Indies and Central America (Castellani, 1956). It has since been isolated occasionally from Portuguese patients who had never been abroad (Professor A. Castellani, personal communication to the National Collection of Type Cultures, 1957). Pigment production was constant only on potato; it occurred occasionally on glucose agar or in gelatin media when these were prepared with American but not English ingredients, but never on nutrient agar. Castellani's original isolate has been investigated and the results are reported here.

\section{METHODS}

Organism. The strain of Micrococcus violagabriellae deposited in the National Collection of Type Cultures by Professor A. Castellani in 1956 as NCTC 9865 was used. The strain had been maintained in the freeze-dried state since shortly after its deposition. A strain of $M$. violagabriellae received from Professor Castellani in December 1963 behaved in a manner identical with that to be described for organism NCTC 9865, apart from its failure to produce acid from glycerol.

Bacteriology. The morphological, cultural and biochemical tests were the routine ones used in this Collection, some of which were listed by Shaw, Stitt \& Cowan (1951).

Pigment production. The optimal conditions were determined by growing the organism on 22 different media at four temperatures $\left(37^{\circ}, 30^{\circ}, 22^{\circ}\right.$, and ambient room temperature, about $15-20^{\circ}$ ), in light and in darkness, in air, in an atmosphere of $\mathrm{CO}_{2}$ and anaerobically.

Nature of the pigment. Attempts to isolate the pigment were made by solvent treatment of the bacterial growth and of aqueous extracts of the pigmented organisms. 


\section{RESULTS}

Biochemically and culturally, the organism corresponded with the description of Staphylococcus saprophyticus (Shaw et al. 1951). In some tests the results were at variance with those of other workers, and these discrepancies are shown in Table 1.

Some pigmentation occurred on mannitol yeast-extract agar, yeast-extract agar, potato slopes and in nutrient gelatin, but was constant and clearly evident only on casein-yeast-lactate-glucose (CYLG) agar (Marshall \& Kelsey, 1960). Growth and pigmentation were best after $48 \mathrm{hr}$ at $30^{\circ}$ on CYLG agar aerobically. There was little difference in pigment production whether incubation was in light or darkness. Pigment was not produced when the cultures were incubated anaerobically and less well than in air when incubated in the presence of $\mathrm{CO}_{2}($ about $10 \%, \mathrm{v} / \mathrm{v})$. By omitting one ingredient in turn from CYLG agar, it was found that the sodium glycerophosphate was not essential for growth or pigmentation. Pigment was not produced in the absence of the inorganic salts solution; this contained iron, magnesium and manganese. Pigment production occurred only in the presence of iron + manganese; magnesium was not required.

Table 1. Biochemical characteristics of Micrococcus violagabriellae according to different workers

\begin{tabular}{|c|c|c|c|c|c|c|}
\hline Test & $\begin{array}{c}\text { Castellani } \\
(\mathbf{1 9 5 5}, \mathbf{1 9 5 6 )}\end{array}$ & $\begin{array}{c}\text { Stocchi } \\
(1956 a, b)\end{array}$ & $\begin{array}{c}\text { Tripodi } \\
\text { (1958) }\end{array}$ & $\begin{array}{l}\text { Cassingena } \\
\text { et al. }(1960)\end{array}$ & $\begin{array}{c}\text { Kocur \& } \\
\text { Martinec } \\
\text { (1963) }\end{array}$ & $\begin{array}{l}\text { This } \\
\text { paper }\end{array}$ \\
\hline Methyl red & + & 0 & $\mathbf{0}$ & + & - & + \\
\hline Voges-Proskauer & - & - & - & 0 & + & + \\
\hline Gelatin liquefaction & + & + & + & - & - & + \\
\hline Milk coagulation & $\begin{array}{l}\text { After } 8-10 \\
\text { days }\end{array}$ & 0 & 0 & + & - & $\begin{array}{c}\text { Rennet } \\
\text { clot }\end{array}$ \\
\hline Urease & 0 & - & - & - & + & + \\
\hline \multicolumn{7}{|l|}{ Acid from } \\
\hline Xylose & $\mathbf{0}$ & - & + & - & - & - \\
\hline Fructose & + & d & - & + & + & + \\
\hline Galactose & - & $\mathbf{0}$ & + & - & + & - \\
\hline Lactose & - & - & - & - & + & - \\
\hline Sucrose & + & - & + & + & + & + \\
\hline Glycerol & 0 & - & - & 0 & + & + \\
\hline Mannitol & - & - & - & - & + & - \\
\hline
\end{tabular}

Key: +, positive; - , negative; d, variable, some strains + , others - ; 0 , information not recorded.

Pigment was not produced by Micrococcus violagabriellae on nutrient agar with or without glucose (1\%); the addition of Marshall \& Kelsey's (1960) inorganic salts solution to these media resulted in some pigmentation. The differences in pigment production noted by Castellani (1956), as between media prepared from English and American fingredients, might be due to variations in their content of trace metals. During observation of this organism for 2 years, non-pigmented variants were not seen on media which induced pigmentation, and organisms from media which did not elicit pigment formation produced pigmented colonies on suitable media. This purple pigmentation was not produced by biochemically similar strains of Staphylococcus saprophyticus or by strains of other staphylococci and micrococci 
examined, when grown under conditions identical with those for $M$. violagabriellae. A greenish-grey pigment was produced by a strain (NCTC 7011) of S. flavo-cyaneus (Knaysi, 1942) but this was not investigated.

\section{Nature of the pigment}

The purple pigment produced by Micrococcus violagabriellae grown on CYLG agar diffused into the medium immediately below the colonies, but not around them. After the bacterial growth had been scraped from the surface of the plates, the brown-purple colour in the medium became pink on the addition of $\mathrm{N}-\mathrm{HCl}$ and yellow with $\mathrm{N}-\mathrm{NaOH}$. The pigment thus acted as a $\mathrm{pH}$ indicator, the colour of which was reversible up to $18 \mathrm{hr}$ after adding acid or alkali to the plates. Neither the colonies nor the pigmented medium exhibited fluorescence under ultraviolet radiation. It was not possible to extract any pigmented material from the organisms by treating the harvested growth with the following solvents : water, $\mathrm{NH}_{4} \mathrm{OH}$ and $\mathrm{NaOH}$ solutions, $\mathrm{HCl}$, acetic, formic or lactic acids, ether, methanol, ethanol, $n$-butanol, sec-butanol, $n$-amyl alcohol, tert-amyl alcohol, capryl alcohol, ethyl acetate, acetone, benzene, toluene, xylene, chloroform, carbon tetrachloride, carbon disulphide, pyridine.

Pigmented material was obtained by the following methods.

(1) The growth from CYLG agar incubated at $30^{\circ}$ for $48 \mathrm{hr}$ was harvested and suspended in distilled water. The suspension was shaken with glass beads for $1 \mathrm{hr}$ on a Kahn shaker and then kept at $4^{\circ}$ overnight. The organisms were removed by gentle centrifugation, and the supernatant fluid treated with $0 \cdot 1 \mathrm{~N}-\mathrm{HCl}$. This resulted in the formation of a flocculent pink-red precipitate; formic acid, lactic acid and $5 \%$ acetic acid in water were also effective.

(2) As in (1), but shaking the supernatant fluid after centrifugation with chloroform, tert-amyl alcohol, or $n$-butanol, when red material collected at the interface of the two liquids.

(3) By storing the harvested suspension of organisms at $37^{\circ}$ for $24 \mathrm{hr}$ considerable autolysis occurred, and small quantities of dark purple liquid could be collected by centrifugation.

(4) Prolonged centrifugation of the suspension of organisms gave a deposit composed of two layers, a thick lower layer of bacteria and a thin upper layer of pigmented material. After centrifugation, pigment could not be demonstrated in the supernatant fluid.

(5) The organism was grown on circles of filter-paper laid on the surface of CYLG agar and incubated at $30^{\circ}$ for $48 \mathrm{hr}$. By this method, pigment did not appear in the medium. The papers were removed and macerated with water, and the suspension was centrifuged and treated with acid as in (1) above.

Method (1) was the most convenient, and pigmented material was obtained by washing the precipitate until the washings were neutral in reaction and chloridefree; the aqueous suspension was finally freeze-dried and a red-purple amorphous solid obtained. This was insoluble in water and the common organic solvents but soluble in concentrated mineral acids. It was insoluble in $\mathrm{NaHCO}_{3}$ solution but dissolved in $\mathrm{N}-\mathrm{NaOH}$ to a yellow solution from which it could be reprecipitated by the addition of acid. A solution in $10 \mathrm{~N}-\mathrm{NaOH}$ deposited a colourless flocculent precipitate after $18 \mathrm{hr}$ at room temperature; after this, the red pigment could not be reprecipitated 
by acid. Qualitative elemental analysis showed the presence of nitrogen, and the absence of halogens, sulphur and phosphorus. Manganese was not detected by the tests used. Iron was detected in the filtrate after gentle ignition of the material and digestion of the residue with dilute $\mathrm{HCl}$. Millon's reaction was negative and reducing sugars were not found.

\section{DISCUSSION}

After its description by Castellani (1955), Micrococcus violagabriellae remained a bacteriological curiosity until Canadian workers found it a valuable organism in studying the effects of ultraviolet irradiation (Payne \& Campbell, 1962, 1963). These workers (1962) found that excess iron was necessary for pigment production and that mutation or selection were not involved. Nichols \& Campbell (1963) reported their preliminary findings on the nature of the pigment of $M$. violagabriellae. In some of its characters it was typical of a melanin but it also contained a pentose and peptide fraction. Iron was present but was removed quantitatively by alkali treatment; it was not thought to be part of the chromophore.

Bacterial pigments may be divided into carotenoids, melanins, phenazines, pyrroles and quinones. The pigments of micrococci and staphylococci are generally thought to be carotenoids and are non-diffusible in aqueous phases but soluble in fat solvents. Castellani (1956) considered that the pigment of Micrococcus violagabriellae was not diffusible; my results appear to oppose this view but it is possible that the pigment is formed extra-cellularly. In its colour-response to $\mathrm{pH}$ change the pigment resembles the red pyrrole derivative prodigiosin produced by Serratia marcescens. The pigment might be called violagabriellin but this has been resisted on the grounds that a trivial name would lose its significance if the same pigment was later found in other bacteria or micro-organisms. It seems better to withhold a name until its chemical structure has been elucidated. Canale-Parola (1963) drew attention to the possible similarity of the pigment of $M$. violagabriellae to pulcherrimin, a red pigment produced by Candida pulcherrima.

Among Gram-positive organisms, red or purple pigments are found in species of Bacillus, Clostridium, Corynebacterium, Micrococcus, Mycobacterium and Streptomyces. A large number of pigmented cocci have been described; those which produce red pigments were discussed by Hucker (1924, 1928), and those with purple pigments by Sneath (1960). The human axilla is a rich source of bacteria and many pigmented cocci have been isolated from this site, for example Micrococcus haematodes (Zopf, 1885), M. chromidrogenus ruber (Trommsdorff, 1904) and M. castellanii (Chalmers \& O'Farrell, 1913). The name M. haematodes was given by Zopf (1885) to an organism described by Babes (1882) as the causative organism of 'red sweat'. Babes noted that the pigment of the organism had properties similar to that of Monas prodigiosus (Serratia marcescens). Unfortunately, cultures of M. haematodes are no longer extant and the original description did not give sufficient information to enable it to be re-identified with certainty. The descriptions given by Flügge (1890), who spelled the specific epithet haematoides, and by Migula (1900), added little fresh information.

Castellani's observation (1955), that pigmentation of Micrococcus violagabriellae varied with the origin of the media constituents, may explain in part the isolated reports of the occurrence of such pigmented organisms. It is possible that the 
organism Castellani described had been described by earlier workers. A review of the literature has not revealed the description of similar organisms other than $M$. moricolor. This was isolated from open wounds of three different patients by Holmes $\&$ Wilson (1945). The description shows a similarity with $\boldsymbol{M}$. violagabriellae but differences are that $M$. moricolor produced acid from lactose but not from maltose or glycerol, acid and coagulation occurred in litmus milk, and non-pigmented variants were often produced after cold storage.

Although Castellani (1955, 1956) named his isolate Micrococcus violagabriellae, he thought that if further study showed it to be a variety of $M$. pyogenes then the name should be $M$. pyogenes var. violagabriellae. Stocchi (1956b) also considered that the organism should be either an autonomous species or a variety of $M$. pyogenes. At that time staphylococci were included in the genus Micrococcus in Bergey's Manual (1948). In a later publication, Castellani (1957) used the binomial Staphylococcus violagabriellae for his isolate. It is certainly a staphylococcus rather than a micrococcus, by the criteria of Baird-Parker (1963) and Jones, Deibel \& Niven (1963); Baird-Parker (personal communication) would include it in his staphylococcus subgroup II. Kocur \& Martinec (1963) were unable to demonstrate pigment production by Castellani's strain, which they considered to belong to the species $S$. epidermidis.

Micrococcus violagabriellae does not seem to have been isolated by workers other than Castellani and it is doubtful whether the apparent rarity of this organism justifies the creation of a separate taxon. It might be considered as a variety of Staphylococcus saprophyticus (Shaw et al. 1951), in which instance the name would be $S$. saprophyticus var. violagabriellae; on the criteria given in Bergey's Manual (1957) the name could be $S$. epidermidis var. violagabriellae. The classification of micrococci and staphylococci is, however, in a state of flux and it would be preferable not to add to the confusion by using new names, until the international subcommittee set up to study the problem has produced a report.

I thank Miss H. E. Ross for translating the older German papers, and G. Kouchajki for technical assistance.

\section{REFERENCES}

BaBEs, V. (1882). Vom roten Schweiss. TermTud. Közl. 14, 36, cited in Biol. Zbl. (1882), $2,255$.

Baird-Parker, A. C. (1963). A classification of micrococei and staphylococci based on physiological and biochemical tests. J. gen. Microbiol. 30, 409.

Bergey's Manual of Determinative Bacteriology (1948). Ed. 6. Ed. by R. S. Breed, E. G. D. Murray \& A. P. Hitchens. London: Baillière, Tindall and Cox.

Bergey's Manual of Determinative Bacteriology (1957). Ed. 7. Ed. by R. S. Breed, E. G. D. Murray \& N. R. Smith. London: Baillière, Tindall and Cox.

Canale-Parola, E. (1963). A red pigment produced by aerobic sporeforming bacteria. Arch. Mikrobiol. 46, 414.

Cassingena, R., Ortali, A. V., Villa, L. \& Milazzo, M. (1960). Micrococcus violagabriellae (Castellani, 1955). R. C. Ist. sup. Sanit. 23, 964.

Castellani, A. (1955). Note préliminaire sur un nouveau microcoque isolé d'une dermatite axillaire superficielle tropicale. Annls Inst. Pasteur, Paris, 89, 475.

Castellani, A. (1956). Erythema axillarum perstans of microcnecal origin. Dermatologica, 113, 202. 
Castellani, A. (1957). A staphylococcus producing a violaceus or purplish pigment when grown on certain media. Bact. Proc. p. 98.

Chalmers, A. J. \& O'FArrell, W. R. (1913). The trichonocardiases. Ann. trop. Med. Parasit. 7, 528.

FuÜGGE, C. (1890). Micro-organisms with special reference to the etiology of the infective diseases. London: The New Sydenham Society.

Holmes, L. F. \& Wilson, M. E. (1945). A micrococcus producing a mulberry-coloured pigment. J. Bact. 49, 311.

HuCKer, G. J. (1924). Studies on the Coccaceae. IV. The classification of genus Micrococcus Cohn. Tech. Bull. N.Y. St. agric. Exp. Sta. no. 102.

Hucker, G. J. (1928). Studies on the Coccaceae. IX. Further studies on the classification of the micrococci. Tech. Bull. N.Y. St. agric. Exp. Stn. no. 135.

Jones, D., Deibel, R. H. \& Niven, C. F., Jr. (1963). Identity of Staphylococcus epidermidis. J. Bact. 85, 62.

KNAYSI, G. (1942). The demonstration of a nucleus in the cell of a staphylococcus. J. Bact. 43, 365.

Kocur, M. \& Martinec, T. (1963). The classification of some violet-pigmented micrococci. J. gen. Microbiol. 32, 185.

MARShall, J. H. \& KeLSEY, J. C. (1960). A standard culture medium for general bacteriology. J. Hyg., Camb. 58, 367.

Migula, W. (1900). System der Bakterien. 2. Specielle Systematik der Bakterien. Jena: Gustav Fischer.

Nichols, J. L. \& Campbeld, J. N. (1963). A red melanin-like pigment from Micrococcus violagabriellae. Bact. Proc. p. 53.

Payne, J. I. \& Campbell, J. N. (1962). The influence of iron on pigmentation and resistance to ultraviolet irradiation in Micrococcus violagabriellae. Bact. Proc. p. 59.

Payne, J. I. \& Campbell, J. N. (1963). Concerning the site of ultraviolet sensitivity in Micrococcus violagabriellae. Bact. Proc. p. 50.

Shaw, C., StrtT, J. M. \& Cowan, S. T. (1951). Staphylococci and their classification. $J$. gen. Microbiol. 5, 1010.

SNeATH, P. H. A. (1960). A study of the bacterial genus Chromobacterium. Ioroa St. J. Sci. 34, 243.

Stocchi, F. (1956a). Osservazioni sul Micrococcus violagabrilleae [sic] Castellani, 1955. Arch. ital. Sci. med. trop. Parassit. 37, 347.

Stосснг, F. (1956b). Ulteriore contributo allo studio del Micrococcus violagabriellae Castellani, 1955. Arch. ital. Sci. med. trop. Parassit. 37, 596.

Tripodi, P. (1958). Ricerche sul Micrococcus violagabriellae Castellani 1955. Arch. ital. Sci. med. trop. Parassit. 39, 551.

TrommsdorfF, R. (1904). Die Bakteriologie der Chromidrosis. Münch. med. Wschr. no. 29, 1285.

Zopf, W. (1885). Die Spaltpilze. 3. Aufl. p. 60. Breslau: E. Trewendt. 